\title{
Preparation, characterization and cytotoxic evaluation of novel au(iii) complexes of thioglycolate and $r$-mercaptoglycolate ligands
}

\author{
N.A. Al-Omari* , N. H.Butrus ${ }^{* *}$ \\ "Deptartment of Pharmaceutical Sciences, College of Pharmacy, ${ }^{*}$ Deptartment of Chemistry, College of \\ Science, University of Mosul, Iraq. \\ $\frac{\text { Received }}{r, 1, r+1} \quad$ Accepted
}

ABSTRACT

Objectives: One of the main goals of the present research is to establish whether any direct correlation exists between the nature of the gold(III) S-ligands and the cytotoxic properties of these compounds.

Methods: The gold(III) complexes $\left[\mathrm{Au}(\mathrm{L})\left(\mathrm{L}^{\prime}\right)_{\mathrm{n}}\right]$; where $\mathrm{L}=\mathrm{SCH}_{\mathrm{r}} \mathrm{COO}^{-} ; \mathrm{L}^{\prime}=$ $\mathrm{HSCH}_{r} \mathrm{COO}^{-}$, were synthesized according to the reported procedure. The cytotoxic evaluation where done by the exposure of the synthesized compounds to HEP- $r$ cell line.

Results: The cytotoxic evaluation revealed that the HEP-r cell line differ in its sensitivity toward the selected complexes compared to cisplatin.

Conclusion: Different arrangement of thioglycolate (L) and r-mercaptoglycolate ( $\left.\mathrm{L}^{\prime}\right)$ ligands around $\mathrm{Au}(\mathrm{III})$ metal core may not be responsible for such different affinities toward synthesized complexes. The increase in sensitivity to gold(III) may imply that these complexes either remain in part as gold(III) species or that one of their metabolites is highly cytotoxic.

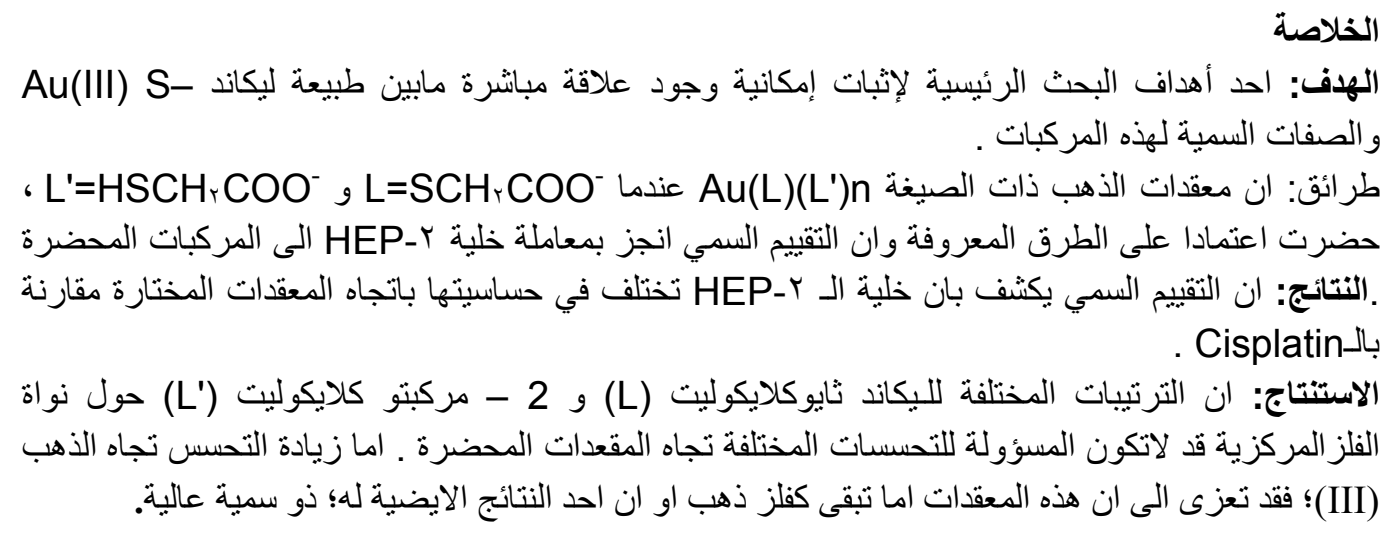

A ccording to the American Cancer Society, cancer was the second leading cause of death in $Y . . T$ '. With cancer at the forefront of health concerns, it is vital that new and improved approaches to treatment are created to eradicate the cancerous cells ; one of the most common approaches is chemotherapy, which oftentimes utilizes bio-inorganic molecules.
Medicinal inorganic chemistry is a thriving area of research ${ }^{r, r}$, which was initially fueled by the discovery of the metallopharmaceutical cisplatin about $\varepsilon$ - years ago. It is widely used to treat testicular, ovarian, bladder and stomach cancers among many others ${ }^{\xi, 0}$. The major limitations of cisplatin and other platinum anticancer drugs are related to drug resistance and their side 
effects, including nephrotoxicity, neurotoxicity and emetogensis ${ }^{\left({ }^{\urcorner}\right)}$. Some cancer cell lines are inherently resistant to cisplatin ${ }^{\gamma}$, whereas others develop resistance overtime ${ }^{\wedge}$. Given these limitations, the development of alternative therapeutics is warranted. Due to the success of cisplatin, much research has been conducted with metal complexes that are analogous to platinum(II).

The design and testing of gold complexes, especially gold(III) complexes with anticancer activity begin to be intensively pursued in the past few years. The potential use of gold(III) complexes as anticancer drugs were based on three rationables, ${ }^{q, '}$ : (a)analogies between square planar complexes of both platinum(II) and gold(III) are $\bullet \mathrm{d}^{\wedge}$ ions ; (b) analogy to the immunomodulatory effects of gold(I) antiarthritic agents ; and (c) complexation of gold(I) and gold(III)with known anticancer agents to form new compounds with enhanced activity.

In addition, a study of the longterm mortality of patients undergoing chrysotherapy, the use of gold(I) in medicine, suggested that cancer levels were no higher or even lower than for patients not undergoing chrysotherapy ",'r. Nevertheless, it really was only in the 191.'s that reports of systematic investigations of the anticancer potential of gold compound started appearing. After a relatively slow start in comparison, investigations on gold(III) compounds have become increasingly important with time. Now, the greatest activity in the development of antitumor active gold compounds currently involves studies of gold in the higher oxidation state.

Although ligands having oxygen and nitrogen as donor atoms are by far the most extensively studied, interest in sulfur donor chelating agents has grow over the years and the number of chemical studies in this area has increased considerably ${ }^{1+-14}$.Interest in complexes of these ligand system now covers several areas, ranging from general considerations of the effect of sulfur and electron delocalization in transition metal complexes of potential biological activity and practical application $^{1 V_{-} r}$.

In this study, two S- ligands : thioglycolate $\left[-\mathrm{SCH}_{\uparrow} \mathrm{COO}^{-}\right](\mathrm{L})$ and $r_{-}$ mercaptoacetic acid $\left[\mathrm{SHCH}_{r} \mathrm{COO}^{-}\right.$] (L') were incorporated as ligands for three considerations :First the cyclic bidentate ligand was seen to reduce rapid detoxification ${ }^{r}$. Secondly, the use of monodentate and bidentate (L) and / or (L') ligands could lead to prevent translabilization and carrying the metal into its site of action .Thirdly the presence of $1 \mathrm{H}$ proton on (L) ligand is ideal for hydrogen bonding with $\mathrm{DNA}^{r, Y r}$, and because that $\mathrm{Au}$ (III) is isoelectrical to Pt (II); a gold based molecule with a flat planar ligand attached might allow for DNA interaction. ( DNA dependent). If so, this might be used as an alternative to cisplatin . Two ligands were incorporated into gold(III) metal center ; thioglycolate $\mathrm{S}-\mathrm{CH}_{r} \mathrm{COOH}(\mathrm{L})$ and $\mathrm{r}_{-}$ mercapto acetate $\mathrm{HSCHCOOH} \mathrm{(L'),}$ but with different distribution around central $\mathrm{Au}$ (III metal). 

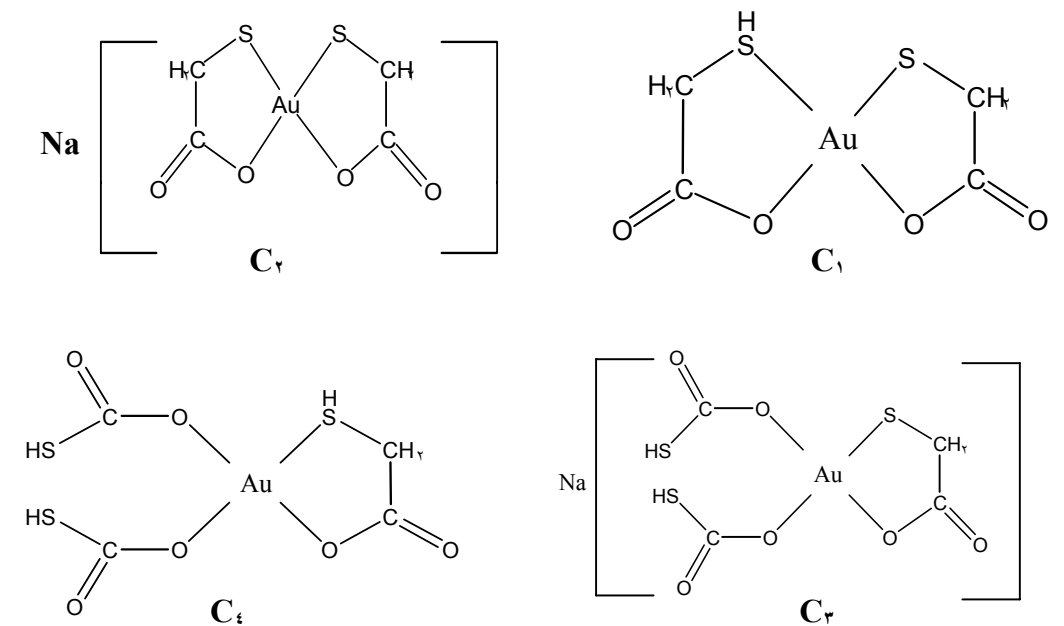

Figure 1: The Chemical structure of the synthesized complexes

Due to the previous literature survey, it is suggested that the synthesized complexes $\mathrm{C}_{1}-\mathrm{C}_{\varepsilon}$ ( figure 1) may be acting by virtue of their chelating properties at the cellular level thereby exerting their anticancer activity .Hence, it was considered worthwhile to subject the presently studied complexes for evaluation of their anticancer activity using Hep-r cell line .

So, one of the main goals of the present research is to establish whether any direct correlation exists between the nature of the S-ligands (L) and (L') ligands and their different arrangements around $\mathrm{Au}(\mathrm{III})$ metal core.

\section{Experimental}

\section{Chemistry}

All chemicals were of reagent grade quality and were purchased from commercial sources (BDH and Fluka). They were used without further purification. IR spectra were recorded on Brucker Tensor rVl. (FTIR) spectrophotometer in the $\left\{\cdots, r \cdot \mathrm{cm}^{-}\right.$ range using CsI disc. Electronic spectra were recorded on Shimadzu
UV 17. spectrophotometer for $1 \cdot^{-r} \mathrm{M}$ solution of the complexes in dimethylformamide using $1 \mathrm{~cm}$ quartz cell. The 'HNMR spectra were recorded on Brucker/ Hims University ,Syria. Spectrophotometer in DMSO-d at room temperature. Conductivity measurements were made on conductivity meter $\varepsilon \cdot v \cdot$ Jenway. The magnetic measurements were carried out at $r 0^{\circ} \mathrm{C}$ on the solid state by Faraday's method using Bruker BM ${ }^{\top}$ instrument. Metal content analyses were made on Shimadzu AATV. atomic absorption spectrophotometer. Elemental Analysis ( $\mathrm{C} \mathrm{H} \mathrm{S}$ ) were carried out using Perkin Elmer $r \leq \ldots$ in Al -Bait 's University /Jordan.

\section{Preparation of disodium $r$. thioglycolate $\left(L^{\prime}\right)$}

The ligand was prepared according to the following general method. The reaction of an equivalent amount of $\mathrm{NaOH} \quad(\varepsilon . \cdots \mathrm{g}, \quad \because \cdot) \mathrm{mol})$ and mercaptoacetic acid sodium salt ( $1.1 \mathrm{r}$ $\mathrm{g}, \cdot \cdot \operatorname{mol})$ in $r \cdot \mathrm{ml}$ ethanol. The mixture was boiled under reflux for $r$ h. The product was obtained through evaporation of the solvent, then the precipitate was washed and 
diethylether, then dried under vacuum for $\leqslant$ hrs.

Preparation of $[\mathrm{Au}(\mathrm{SCH}+\mathrm{CO})(\mathrm{OC}-$ $\left.\mathrm{CH}_{r} \mathrm{SH}\right]\left(\mathrm{C}_{\text {}}\right)$

A solution of $\mathrm{H}\left[\mathrm{AuCl}_{\varepsilon}\right](\cdot r \varepsilon \mathrm{g}, \cdot \cdot \cdot)$ mol.) in $10 \mathrm{ml}$., ethanol was added to a stirred solution of the ligand mercaptoacetic acid sodium salt $(\cdot.) \mathrm{g}$, $\because \cdots 1 \mathrm{ml}$.) and disodium thioglycolate $(\cdot.) \leq \mathrm{g}, \cdot \cdot \cdot$ ) mol.) in $1 \cdot \mathrm{ml}$ ethanol. The reaction mixture was refluxed for $r \mathrm{~h}$ and then the mixture was left $r \leq h$ at room temperature to give the precipitate which was filtered off, washed with ethanol and diethylether and then dried under vacuum for $\leqslant \mathrm{h}$.

\section{Preparation of $\left.\mathrm{Na}\left[\mathrm{Au} \mathrm{SCH}_{\uparrow} \mathrm{COO}\right)_{\uparrow}\right]$} $\left(C_{r}\right)$

A solution of $\mathrm{H}\left[\mathrm{AuCl}_{\varepsilon}\right](\cdot r \varepsilon \mathrm{g}, \cdot \cdot \cdot)$ $\mathrm{mol}$ ) in $10 \mathrm{ml}$ ethanol was added to a stirred solution of the ligand disodium thioglycalate $(\cdot r \wedge \mathrm{g}, \because \cdots r \mathrm{~mol}$.) in ethanol $(10 \mathrm{ml})$. The addition was continued for. $.0 \mathrm{~h}$ and the reaction mixture was refluxed for $r \mathrm{~h}$; and then the mixture was left for $r \leq h$ at room temperature to give the precipitate which was filtered off, washed with ethanol and diethylether then dried under vacuum for several hours.

\section{Preparation of $\mathrm{Na}[\mathrm{Au}$ $\left.\left(\mathrm{OCOCH}_{\uparrow} \mathrm{SH}\right)_{\curlyvee}\left(\mathrm{OCOCH}_{\uparrow} \mathrm{S}\right)\right] \quad\left(\mathrm{C}_{\uparrow}\right)$}

A solution of $\mathrm{H}\left[\mathrm{AuCl}_{\varepsilon}\right](\cdot r \varepsilon \mathrm{g}, \cdot \cdots)$ mol.) in $10 \mathrm{ml}$ ethanol was added to a solution of the ligands, mercaptoacetic acid sodium salt $\left(\cdot r r\right.$ g., $\because{ }^{r}$ rmol. $)$ and disodium thioglycolate $(\cdot) \leq \mathrm{g}$, $\because \cdots$ mol.) in r. $\mathrm{ml}$ ethanol. The addition was continued for $\cdot{ }^{\circ} \mathrm{h}$. and the reaction mixture was refluxed for $r$ $h$ and then the mixture was left $r \leqslant h$ at room temperature to give the precipitate which was filtered off, washed with ethanol and diethyl ether then dried under vacuum for several hours.

Preparation of $\left[\mathrm{Au}\left(\mathrm{OCOCH} \mathrm{H}_{\uparrow} \mathrm{SH}\right)_{\uparrow}\right]$ (C)

This complex was prepared as in above, except the use of $r$ moles of the ligand mercaptoacetic acid sodium salt.

\section{Stability in Buffer}

stability tests were run on compound $\mathrm{C}_{r} \& \mathrm{C}_{r}$ which were used as a representive compounds. A minimum amount of dimethyl sulfoxide (DMSO) was used to dissolve the complex, which was then diluted in phosphate buffer ( $\left.\mathrm{pH} \quad v_{.} \varepsilon\right)$, a solution of concentration $0 . *^{*} 1 .{ }^{-0} \mathrm{M}$ was made and observed daily for a period of $r$ days. The sample was stored in a dark environment throughout the r-day period. There appears to be no significant shift in the absorption maxima at $r$ r. nm, which is the absorption that arises due to the gold(III) metal ion.

\section{Cytotoxic study}

\section{Preliminary cytotoxic test}

\section{Cell line and growth conditions}

Human Larynx epidermoid carcinoma (Hep- $r$ ) was kindly provided by the Iraqi center for Cancer and Medical Genetics Research ICCMGR). This human cells grew rapidly, doubling themselves in r-r days and were shown to be extremely resistant to ultraviolet rays ${ }^{(r)}$ \& were grown in Rosswell Park Memorial Institute (RPMI) $17 \varepsilon \cdot$ Medium (Gibco ,USA), which was prepared as follows

- RPMI 17๕. medium powder was dissolved in approximately $\%$. $\mathrm{ml}$ of double distilled water 
(DDW) and then the other components added :

- $\quad \because 0 \mathrm{ml}$, Streptomycin ( $\mathrm{g} /{ }^{\circ}$ $\mathrm{ml}$ )

- Sodium bicarbonate ( $₹ . \% \%)$ $10 \mathrm{ml}$ to give the final $\mathrm{pH}$ of V.Y Sodium bicarbonate solution was prepared by dissolving $\leqslant$. g. in $1 \cdots \mathrm{ml}$ D.W. The solution was autoclaved at $\mid r 1^{\circ}$ for 10 minutes and stored at $\varepsilon$ ${ }^{\circ} \mathrm{C}^{r \xi}$

- $\quad 0^{\circ} \mathrm{ml}$ Benzyl Penicillin G ( 7 .. I U $/ 0 \mathrm{ml})$

- r.॰ mg Amphotericin B .

- $\quad 1$. ml Fetal calf serum

The volume was completed to one liter with DDW. Then the mixture was sterilized using Seitz filter and filtration repeated using $\cdot r \quad \mathrm{~m}$ filter unit. The sterilization was done in a sterile environment, then stored at $\varepsilon$ $\mathrm{C}$ for direct use. All antibiotics were freshly prepared .

The growth medium was decanted off and the cell sheet washed twice with phosphate buffered saline (PBS), composed of :

- Sodium chloride $(\mathrm{NaCl}) \wedge$ g.

- Disodium hydrogen phosphate

$(\mathrm{Na}$ rHPO $\varepsilon)$ $\because 9 \mathrm{~g}$.

- Potassium dihydrogen phosphate $\left(\mathrm{KH}_{\uparrow} \mathrm{PO}_{\varepsilon}\right) \cdot r$ g.

After dissolving all components, the solution was autoclaved at $1 \% 1{ }^{\circ} \mathrm{C}$ for $10 \mathrm{~min}$ and then stored at $\varepsilon^{\circ} \mathrm{C}$ prior to any usage, PBS was warmed to ${ }^{r}{ }^{\circ} \mathrm{C}$.

Cells were regularly subcultured when monolayers were confluent. Two to three $\mathrm{ml}$ of warm trypsin-versene (prepared by mixing $Y$. $\mathrm{ml}$ of trypsin solution, $1 \cdot \mathrm{ml}$ of versene solution and $r v \cdot \mathrm{ml}$ PBS and stored at $\left.\Sigma^{\circ} \mathrm{C}\right)$. were added to the sheet and the flask rocked gently ${ }^{(\Upsilon \varepsilon)}$.

Preparationof ${ }^{\top}$-(Dimethylthiazol- ${ }^{r}$ yl)- $r, \bullet-D i p h e n y l t e t r a z o l i u m b r o m i d$ (MTT) solution (Sigma ,USA).

Fifty milligram per $\mathrm{ml}$ of MTT dye was used as a final concentration (ro) .The solution was filtered through $\cdot . r r$ $\mu$ syringe filter to remove any blue formazan product ${ }^{(\top)}$, and then stored in sterile , dark ,screw -capped bottles at $\leqslant{ }^{\circ} \mathrm{C}$.

The solution was used within no longer than ${ }^{r}$ weeks of preparation .

\section{Cytotoxic Assay on Hep- $r$ Cell Line}

This step must be prepared under aseptic condition ${ }^{\Upsilon \vee}, \uparrow \wedge$. All complexes $\left(\mathrm{C}_{1}-\mathrm{C}_{\varepsilon}\right)$ were prepared for micotitration assay by dissolving $r$ mg. of each compound in $r \mathrm{ml}$ of solvent $(\cdot r \mathrm{ml}$ DMSO \& 1.^ $\mathrm{ml}$ DDW, the stock concentration is $\quad \cdots \mu \mathrm{g} / \mathrm{ml}$ )and filtered by $\cdot r r \mu$ Millipore filter .Serial dilutions of each compound

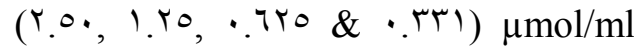
under assay in SFM were added to the well. Three replicates were used for each concentration of either four tested complexes in addition to cisplatin (EBEWE, Austria Europe) as a reference (D:positive control)

When the cells are exactly in the exponential phase in the population doubling time (PDT), then the cells in full of their activity, the cells were collected after adding trypsin/versin $\left(T_{-}\right.$ 
$r \mathrm{ml}$ ) not more than 1. min., then concentrated into known volume with SFM. Afterwards, $\because \mathrm{ml}$ of cells in growth medium were added to each well of sterile 97 -well micro titration plate. The plate were sealed with a self adhesive filer, placed on $\mathrm{CO}_{r}$ incubator at $\mathrm{rV}^{\circ} \mathrm{C}$ for not more than $r \varepsilon \mathrm{hrs}$. (for cell adherence) .After cells attachment, the plate was checked -out for contamination and the media were removed .Serial concentrations were added and three replicates were used to each concentration and negative control (cell with SFM only), the exposure time was $\mathrm{V} r \mathrm{hrs}$.

After the exposure time was finished, the mixtures of analogues and media were removed and a fresh SFM was added to all wells , and incubated for $r \leqslant \mathrm{hrs}$ at $r v{ }^{\circ} \mathrm{C}$ to give chance if the affected cells and not damaged being repaired by self repairing system .Then the media was removed from the plate and washed PBS .A $\because r \mathrm{ml}$ of MTT working solution dye was added to each well and incubated at $r v{ }^{\circ} \mathrm{C}$ for $r$ hrs.

At the end of last incubation period the dye was removed from the plate and the well washed with warm PBS twice, then $\cdot r \mathrm{ml} \mathrm{DMSO}$ was added to each well to dissolve the MTT -formazan crystals, during that we added to $\mu$ of glycine buffer to each well containing DMSO.

Finally the plate became readily for reading by ELISA reader at ov $\cdot \mathrm{nm}$.

\section{Statistical Analysis}

Experimental data were analyzed using statistical software SPSS IV. for Windows. Significance between control and samples was determined using Students' t-test. A P value $\leq . . \bullet$ was considered statistically significant.

The results were expressed as percentage of viability which was calculated as the percentage of the mean of absorbance compound to the control.

The ICo., which is the lowest concentration that kill $0 . \%$ of cells ${ }^{r v}$ was calculated according to Wilson ${ }^{r \wedge}$.

\section{Results and Discussion \\ Chemistry}

The thioglycolate ligands form stable, colored solid and acts as monodentate (O) and bidentate $(\mathrm{O} / \mathrm{S})$ with $\mathrm{Au}(\mathrm{III})$ ion. All complexes are thermally stable and insoluble in organic solvents. However, fair solubility was attributed in DMF and DMSO. The $1 \cdot^{-r} \mathrm{M}$ solution in DMSO $\mathrm{C}_{r}$ and $\mathrm{C}_{r}$ display molar conductance equal to $\mathrm{V} \cdot$ and $\Lambda$. $\mathrm{ohm}^{-1} \mathrm{~cm}^{-r} \mathrm{~mol}^{-1}$ indicating a $1: r$ electrolytic nature of the complexes, where as for the rest of the complexes the

value $1 \cdot-r \cdot \mathrm{ohm}^{-1} \mathrm{~cm}^{-r} \mathrm{~mol}{ }^{-1}$ indicating non electrolytic nature of the complexes $^{r q}$.This is consistent with stoichiometry for the complexes on the basis of analytical data.

The most important diagnostic feature of IR spectra of the complexes were listed in Table $r$. The most significant information on the geometry of these complexes were came from the analysis of caboxylate and thioether absorption region. Stretching frequencies of these functional groups are closely related to the way in which they are coordinated to the metal ion ${ }^{r}$. The IR spectra of the complexes showed broad and intense bands ranging between 101.- 
17 ro and $\left.1 \leqslant 10_{-}\right) \leqslant \vee 0 \mathrm{~cm}^{-1}$ assigned for asym $v\left(\mathrm{COO}^{-1}\right)$ and for sym. $v\left(\mathrm{COO}^{-}\right.$ ') respectively.(Table $r$ ).

The magnitude of $\Delta v(\Delta v=v$ asym $\mathrm{COO}-v$ sym $\mathrm{COO}^{)}$were in the range $10 .-11 . \mathrm{cm}^{-1}$ suggested monodentate bonding of carboxylic group to metal ion ${ }^{r}$.

Further support for this argument came from the IR of the complexes which showed a new band at $\leqslant 79_{-} \leqslant \wedge 7$ $\mathrm{cm}^{-1}$ attributable $v$ (Au-O)., The (C-S) band of the ligand was observed at $\wedge \mathrm{r}$. $\mathrm{cm}^{-1}$, upon coordination with metal ions in complexes it was shifted to lower frequency values (Table $r$ ).Further support for this coordination has provided from the appearance of new bands in the $r \leq \cdot-r \tau \cdot \mathrm{cm}^{-1}$ ranges which are tentatively attributed to $v(\mathrm{Au}-\mathrm{S})^{r}$.

The 'HNMR spectra of the complexes ( $(-\varepsilon)$ were recorded in DMSO $d_{\uparrow}$ and showed the signal of the coordinated ligands, NMR data are explained below. For $\mathbf{C}_{1}$, Shows, broad band at r.r'which can be attributed to each $\mathrm{CH}_{r}$ proton in the $\mathrm{S}$ $\mathrm{CH}_{\uparrow} \mathrm{CO}$ moiety and a band at $) . \wedge$ ppm which attributed to $\mathrm{SH}$ proton.

$C_{r}$,shows only one band which can be attributed to each $\mathrm{CH}_{r}$ proton in the $\mathrm{S}-\mathrm{CH}_{r} \mathrm{CO}$ group of each ligand at

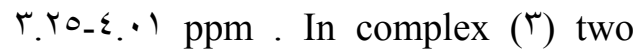
bands can be assigned to each $\mathrm{CH}_{r}$ in the $\mathrm{SCH}_{r} \mathrm{CO}$ at r-ros ppm and the thiol protons of $1 . \cdot V$ and $', r$ ppm, for complex $\varepsilon$ same as $r$.

The diamagnetic nature of the $\mathrm{Au}(\mathrm{III})$ complexes is consistent with normal square-planar geometry around $\mathrm{Au}(\mathrm{III})$ ion $^{r}$.

Electronic absorption spectra of the complexes in DMF are listed in Table $r$ in the spectrum of the ligand the $\pi$ $\pi^{*}$ transition were observed at rurrr and $r \mathrm{r} \cdot \cdot \mathrm{cm}^{-1}$.

The spectrum of the complexes show new bands at ro...- r 7 r YVY $\leqslant \Lambda_{-}$Y Y $\leqslant 0 \mathrm{~cm}^{-1}$ assigned to ${ }^{\prime} \mathrm{A}_{\mathrm{g}} \rightarrow$ ${ }^{\prime} \mathrm{A}_{\mathrm{rg}}$ and ' $\mathrm{A}_{\mathrm{ig}} \rightarrow{ }^{\prime} \mathrm{E}_{\mathrm{g}}$ transition respectively ${ }^{r \varepsilon}$, these bands correspond fairly well to a square planar geometry around the $\mathrm{Au}(\mathrm{III})$ ion. Also the band at $\leqslant .0 . \mathrm{cm}^{-1}$ is tentatively assigned as ligand charge transfer transition. Similar results were found in $\mathrm{Pt}(\mathrm{II})$ and $\mathrm{Au}(\mathrm{III})$ complexes of the $\left[\mathrm{M}\right.$ (diimine)(dithiolate) type $^{\mathrm{ro}^{\circ}}$.

The ligands used in this study, coordinate to the $\mathrm{Au}(\mathrm{III})$ ions in monodentate or bidentate fashion from both oxygen and sulfur atom of thioglycolate group. The suggested structures of the prepared complexes were according to the reaction molar ratios and all physico-chemical properties as indicated in Figure !.

\section{Cytotoxic study}

Gold(III) compounds are emerging as a new class of metal complexes with outstanding cytotoxic properties and are presently being evaluated as potential biologically active \& specifically as antitumor agents $^{\text {ru-rq }}$.

Given the strict similarity to cisplatin, gold(III) complexes are of interest for two main reasons : on the one side, they may constitute a new class of anticancer compounds with a novel profile of antitumor activity ; on the other side, they represent a further attempt to elucidate the mechanism of action of antitumor $d^{\wedge}$ square planar metal complexes, which still remains largely unknown ${ }^{\text {. }}$. 
Methylthiazoletetrazolium (MTT) assay was employed to assess cell viability. MTT assay was based on the ability of the viable cells to reduce soluble yellow MTT to blue formazan crystals .In this assay, optical density (OD) values represented the absorption of formazan dissolved by $\mathrm{DMSO}$ at $\bullet \mathrm{V} \cdot \mathrm{nm}^{\mathrm{r}}$.

The evaluation of the cytotoxic properties of synthesized $\mathrm{Au}(\mathrm{III})$ complex $\left(\mathrm{C}_{1}-\mathrm{C}_{\varepsilon}\right)$ were tested against HEP-r cell line; well known resisted to

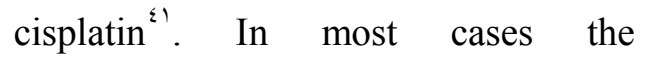
investigated compounds showed relevant in vitro anticancer properties with ICo. values generally falling in the low $\mu \mathrm{M}$ concentration $(\sim \cdot \cdot \mu \mathrm{M})$ ,additionally, these compounds turned out to overcome largely resistance of HEP-r cell line to cisplatin ( Figure $r$ and Figure ${ }^{\top}$ ).

Concerning their physiological stability, the $\mathrm{Cr}_{r}$ and $\mathrm{Cr}_{r} \mathrm{Au}$ (III) complexes bearing $\mathrm{S}$ - ligands motif, showed acceptable stability within physiological like environment, and important cytotoxic properties.

The application of T-test, show that the potency parameter ( IC. . )of the tested complexes $\left(\mathrm{C}_{1}-\mathrm{C}_{\varepsilon}\right)$, although not significant, it represent high potency compared to the reference compound, the lack of cross-resistance suggests that gold (III) induce cytotoxicity through different mechanism .So ,S-ligands (L) and (L') are crucial both in stabilizing the $\mathrm{Au}$ (III) center and in carrying the metal to its cellular targets $^{\text {sr }}$ i.e. to pharmacokinetic.

It may be ruled out that there is no correlation between different arrangement of ligands (L) and (L') whether monodentate or bidentate, planar or pentacyclic, and neutral or charged around central metal,. Such a finding allows us to state that the presence of $\mathrm{H}$ in sulfur-donor ligand is not an essential requirement for cytotoxicity in gold(III) complexes, i.e. to pharmacodynemic.

Since, the cytotoxic profile of synthesized complexes is largely differ to cisplatin, it may come in agreement with many literatures stated that $\mathrm{Au}$ (III) were found to perturbs greatly the mitochondrial function ${ }^{\varepsilon-\varepsilon 0}$.

This hypothesis is further reinforced by the observation that antiarthritis $\mathrm{Au}(\mathrm{I})$ compounds such as; Auranofin , are known as potent inhibitors of thioredoxin reductase and as effective antimitochondrial agent ${ }^{\varepsilon \eta, \xi v}$.

The fact that measured cytotoxicity is nevertheless relevant, may imply that these complexes either remain in part as a gold(III) species and is quickly taken up by cells as such or that one of its metabolites is highly cytotoxic, this may come with agreement that $\mathrm{Au}(\mathrm{III})$ complexes may exerts their cytotoxic activity in different way to its isoelectronic and isostructural to $\mathrm{Pt}(\mathrm{II})$, hence, the nuclear DNA is not their ultimate target (DNA independent) ${ }^{\varepsilon \leqslant}$.

\section{Conclusion}

The cytotoxicity of the synthesized gold (III) is strictly related to the presence of the gold (III) center , and that $C_{1}-C_{\varepsilon}$ are significantly more cytotoxic than cisplatin.

- Using different arrangement of S-ligand around central $\mathrm{Au}(\mathrm{III})$ atom appear to have no significant role in cytotoxic activity (non essential 
modifications) of these complexes.

- Thiol-ligand is no more being neglected in $\mathrm{Au}(\mathrm{III})$ complexes, although $\mathrm{Au}(\mathrm{III})$ isoelectrical with $\mathrm{Pt}(\mathrm{II})$, suggests that the binding occurs with the gold(III) metal center or one of it metabolite (DNA independent).

- Different arrangement of thioglycolic molecule around $\mathrm{Au}(\mathrm{III})$ metal core may or may not be responsible for such different affinities toward synthesized compared to positive control (cisplatin).

- The amount of gold (III) that enters in the cells is roughly proportional to the exposure time , at least during the first hours.

It is clear, after all these evidences, that $\mathrm{Au}(\mathrm{III})$ complexes represent an interesting family of cytotoxic agents due to the peculiar chemical and biological properties and further researches have to be developed.

Table '. Physical Properties of the $C_{1}-C_{\varepsilon}$ complexes:

\begin{tabular}{|c|c|c|c|c|c|c|c|c|c|c|}
\hline \multirow[t]{2}{*}{ No } & \multirow[t]{2}{*}{ Complex } & \multirow{2}{*}{ Color } & \multirow{2}{*}{$\begin{array}{l}\text { m.p. } \\
\left({ }^{\circ} \mathrm{C}\right)\end{array}$} & \multirow{2}{*}{$\begin{array}{c}\text { Yiel } \\
\text { d } \\
\%\end{array}$} & \multicolumn{4}{|c|}{$\begin{array}{l}\text { Elemental analysis \% Found } \\
\text { (calc.) }\end{array}$} & \multirow{2}{*}{$\begin{array}{c}\Lambda_{\text {ohm }} \\
-1\end{array}$} & \multirow{2}{*}{$\begin{array}{c}\mu_{\text {eff }} \\
(B . M \\
\quad)\end{array}$} \\
\hline & & & & & $\mathrm{C}$ & & $\begin{array}{l}\mathrm{H} \\
\mathrm{Au}\end{array}$ & $\mathrm{S}$ & & \\
\hline 1 & $\begin{array}{c}{\left[\mathrm{Au}\left(\mathrm{SCH}_{r} \mathrm{COO}\right)\right.} \\
\left.\left(\mathrm{HSCH}_{r} \mathrm{COO}\right)\right]\end{array}$ & $\begin{array}{l}\text { Dark } \\
\text { green }\end{array}$ & $r \leqslant \gamma^{d}$ & 70 & $\begin{array}{c}\mid r .71 \\
(1 Y .79 \\
)\end{array}$ & 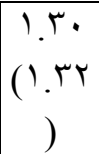 & $\begin{array}{c}17.19 \\
(17.94 \\
)\end{array}$ & $\begin{array}{c}0 . . \mathrm{VY} \\
(0 . . \mathrm{Vq} \\
)\end{array}$ & 1 . & Dia \\
\hline$r$ & $\mathrm{Na}\left[\mathrm{Au}\left(\mathrm{SCH}_{r} \mathrm{COO}\right)_{r}\right]$ & $\begin{array}{c}\text { Dark } \\
\text { brown }\end{array}$ & $\begin{array}{c}>r v \\
0\end{array}$ & $V T$ & $\begin{array}{c}11.90 \\
(15 . \cdots \\
\text { ) }\end{array}$ & $\begin{array}{c}1, \cdots \\
(1 . \cdots \\
)\end{array}$ & $\begin{array}{c}10.94 \\
(17 . \cdots \\
)\end{array}$ & $\begin{array}{l}\leqslant 9.19 \\
\leqslant 9.10\end{array}$ & 19 & Dia \\
\hline$r$ & $\begin{array}{c}\mathrm{Na}\left[\mathrm{Au}\left(\mathrm{HSCH}_{\uparrow} \mathrm{COO}\right)\right. \\
r \\
\left.\left(\mathrm{SCH}_{r} \mathrm{COO}\right)\right]\end{array}$ & $\begin{array}{c}\text { Pale } \\
\text { brown }\end{array}$ & r). d & $V$. & $\begin{array}{c}1 \leq .7 . \\
(1 \leq .74 \\
)\end{array}$ & $\begin{array}{c}1.71 \\
(1.74 \\
)\end{array}$ & $\begin{array}{c}19.59 \\
(19.01 \\
)\end{array}$ & $\begin{array}{c}\varepsilon \cdot \cdots \\
\varepsilon \cdot \cdot \varepsilon \\
)\end{array}$ & ir & Dia \\
\hline$\varepsilon$ & {$\left[\mathrm{Au}\left(\mathrm{SHCH}_{\uparrow} \mathrm{COO}\right)_{r}\right]$} & $\begin{array}{c}\text { Brow } \\
n\end{array}$ & r...d & 79 & $\begin{array}{c}1 \leq . \vee 1 \\
(1 \leq . \vee \wedge \\
)\end{array}$ & $\begin{array}{c}1 . r \cdot \\
(1 . r+r \\
)\end{array}$ & $\begin{array}{c}19.79 \\
(19.71 \\
)\end{array}$ & $\begin{array}{c}\varepsilon \cdot . \Gamma_{0} \\
(\varepsilon \cdot . \leqslant 0 \\
)\end{array}$ & 11 & Dia \\
\hline
\end{tabular}


Table $r$. Electronic and Infrared Specification of the complexes

\begin{tabular}{|c|c|c|c|c|c|c|c|c|}
\hline \multirow[b]{2}{*}{ No. } & \multirow{2}{*}{$\begin{array}{c}\text { UV. VIS } \\
\left.\lambda_{\max } \mathrm{Cm}^{-1}\right)\end{array}$} & \multicolumn{7}{|c|}{ IR bands $\left(\mathrm{cm}^{-1}\right)$} \\
\hline & & $\begin{array}{c}v \\
\text { asy.(Coo) }\end{array}$ & $\begin{array}{c}v \\
\operatorname{sym} .(\mathrm{Coo})\end{array}$ & $\begin{array}{c}\Delta \mathrm{v}(v \\
\text { asy- } v \\
\text { sym })\end{array}$ & $\begin{array}{c}v(\mathrm{c}- \\
\mathrm{s})\end{array}$ & $\begin{array}{c}v(\mathrm{Au}- \\
\mathrm{o})\end{array}$ & $\begin{array}{c}v \\
(\mathrm{Au}- \\
\mathrm{s})\end{array}$ & $\begin{array}{c}v \\
(\mathrm{Au}- \\
\mathrm{d})\end{array}$ \\
\hline$T$ & $\begin{array}{c}\text { TY.., YVY } \\
\leqslant \leqslant, 0 .\end{array}$ & $1710 \mathrm{Vs}$ & $1 \leq 70_{\mathrm{S}}$ & 10. & $\Lambda \Sigma r_{S}$ & $\varepsilon 79 \mathrm{~m}$ & $r \leqslant 0 \mathrm{~m}$ & --- \\
\hline$T$ & $\begin{array}{c}r \cdot 11 \cdot, r \wedge \ldots, \\
\text { ro... }\end{array}$ & $171 \cdot 5$ & $1 \leqslant 0 \cdot s$ & 17. & $10 . \mathrm{s}$ & $\varepsilon \wedge \cdot m$ & $\mathrm{ro0} \mathrm{W}$ & --- \\
\hline$r$ & Yง7า ,YO... & $17 r \sigma_{S}$ & $1 \leqslant V \cdot s$ & 100 & $\lambda r q_{S}$ & $\varepsilon V \cdot s$ & ru.W & --- \\
\hline$\varepsilon$ & r90.., ro... & $17 \pi \cdot s$ & $1 \leq 7 \cdot 5$ & IV. & $\lambda \leqslant r_{S}$ & $\varepsilon \wedge 0_{\mathrm{m}}$ & ro.m & --- \\
\hline
\end{tabular}

$\mathrm{vs}=$ very strong $\mathrm{s}=$ strong $\mathrm{m}=$ medium $\mathrm{w}=$ weak

Table ${ }^{r}$. IC . of $\mathrm{C}_{1}-\mathrm{C}_{\varepsilon}$ compared to cisplatin

\begin{tabular}{|c|c|c|c|c|}
\hline C) & $\mathrm{Cr}_{r}$ & $\mathrm{Cr}_{r}$ & $\mathrm{C}_{\varepsilon}$ & D (cisplatin) \\
\hline.$r q$ & $\therefore \leqslant 0$ & $\because \leqslant 0$ & $\cdot$ TYO & דוז. \\
\hline
\end{tabular}

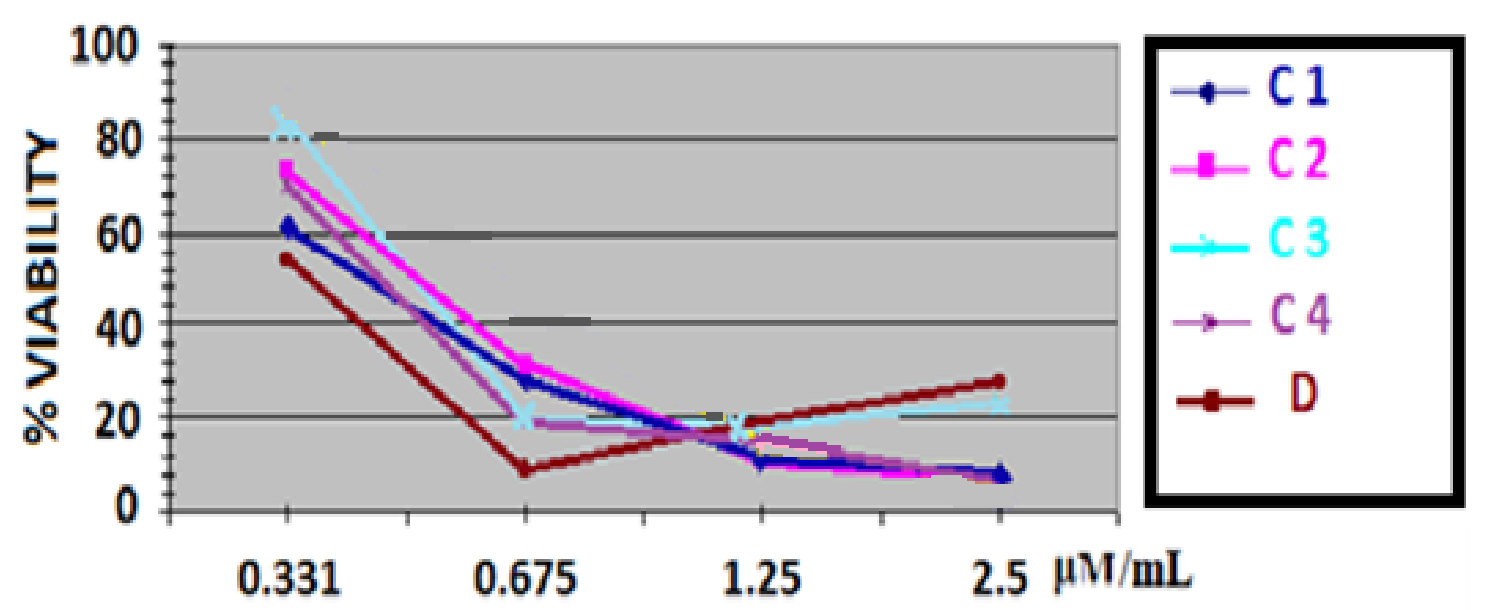

Figure $\uparrow$. Different $\%$ viability of the synthesized complexes 


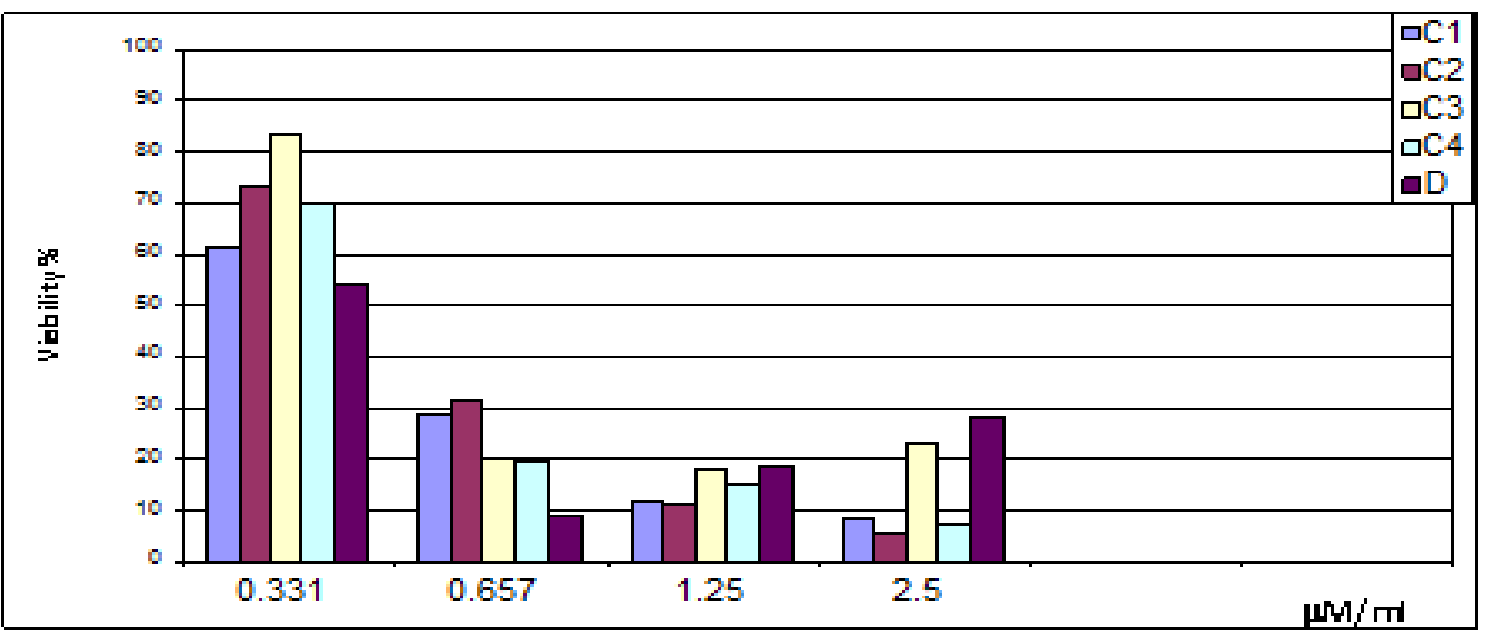

Figure $r$. Histogram of the synthesized complexes

\section{References}

1. American Cancer Society .www.cancer.org.

r. Sadler PJ, Berlini I, Gray HB, et al. Metal in Medicine. In Biological Inorganic Chemistry: Structure and Reactivity, r..v; $\left.90_{-}\right)$ro.

r. Storr T. Design of targeting ligands in medicinal inorganic chemistry. Chem Soc Rev r. . r; ro:0r

$\varepsilon$. Trzaska S. Cisplatin chemical and engineering news. r... , ^r, ro.

○. Tieknik RT. Review: Anticancer potential of gold complexes.

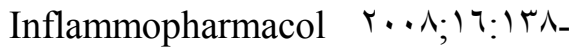
$\varepsilon r$.

7. Wong E, Giandornenico CM. Current status of platinum-based antitumor drugs. Chemical Review 1999;99:Y $\leqslant 01$ - 77.

V. Kelland 1R. Cisplatin :chemistry and biochemistry of a leading anticancer Drug .Lipper B. (ed.) Helvetica Chimica Acta 1999:々91.
^. Kelland
LR.
Preclinical perspectives on platinum

resistance. Drugs $\quad$.... $\circ 9$, Suppl. «: \-^.

१. Haiduc I, Silvestru C. Rhodium, iridium, copper and gold antitumor organometallic compounds

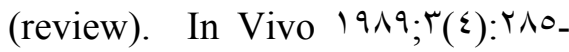
9 \%.

1. Shaw CF. Ruthenium III Compound in Cancer Therapy " in Metal Compounds in Cancer Therapy, S.P.Fricker, ed., Chapman \& Hall, London, UK, 199 纟.pp 70_91.

11. Fries JF, Bloch D, Spitz P, Mitshell DM. Cancer in rheumatoid arthritis: a perspective long term study of mortality .Am J Med 19^०; $\vee \wedge(S u p p l . ~ ' A): 07 \_9$.

Ir. Yei HSm Tiekink RT. Gold-based metallotherapeutic: use and potential. metallotherapeutic drugs and metal-based diagnostic agents: the use of metal in medicine. $Y . .0$.

1r. Ali MA, Livingstone SE. Metal complexes of sulfur-nitrogen chelating agent .Coordination 
Chemistry Review. 19vะ;1r:1.1. rr.

I . Sathisha MP, Revanker VK, Pai KSR. Synthesis structure ,electochemistry ,and spectral characterization of bis-isiatin thiocarbohydrazone metal complexes and their antitumor activity against ehrlich ascites carcinoma in swiss albino mice. Metal Based Drugs, ץ...; Artish ID rTr 1.0, $11 \mathrm{P}$.

10. Butrus NH, AbdAlRazaq EA, AlSger AK. Synthesis and characterization of some new dinuclear platinum (ii) complexes containing $\quad, 1, Y, r_{-}$tetraxis ( substituted phenyl thio ) ethylene. Int J Chem Sci r..V;O(r): $1111-r \cdot$.

17. Abd AlRazaq EA, Butrus NH, Abed Al-Rahman A.A. Synthesis and Characterization of Gold (III) Complexes with Bis - ( $1, \varepsilon-$ Sodium Thioglycolate ) butane Ligand. $r \cdot 1 \cdot ; r(r), ~ Y \backslash \vee q_{\text {_A }}$.

IV. Stunzi H. Can Chelation be Important in the antiviral activity of isiatin B- thiosemicabazones? Australian J Chem 19人r;ro(7): 11) 10.00

1^. Campbell MJM. Transition metal complexes of semicarbazone and thiosemicarbazone . Coordination Chemistry Review . 19v0;10(r. r): rVq_- 19 .

19. Padhye SB, Kauffman GB. Transition metal complexes of semicarbazones and thiosemicarbazones .Coord Chem Rev (1910;7T:1 TV_T.

$r \cdot$ Akrivos PD. Coord Chem Rev r...; r|r:111.

r). Fatima G, Oztekin A, Hatice E. Eur J Chem. r..r; r^: $\leqslant \vee r$. r. Al Omari NA. Synthesis and characterization of new palladium, platinum (ii) and platinum) (iv) cisplatin analogues with biologically active ligand nitrone compounds as ligands and study the cytotoxic activity against hep- $r$ cell line. ${ }^{\prime} .{ }^{7}$; $\mathrm{PhD}$ thesis. University of Baghdad, College of pharmacy.

rr. Moore AE, Sabachewesky L, Toolen HW. Culture characteristics of four permanent lines of human cancer cells .Cancer Res 1900;10:091_.7.0.

$r \varepsilon$. Yassen NY. Cytogenetic study on human colorectal cancer cell. 199.; $\mathrm{PhD}$ Thesis, University of Sheffield, UK.

ro. Freshney RI. Culture of Animal Cells: A manual for Basic Technique. Y... ; 0 th ed. .Wileyliss, A John Wiley \& Sons ,Inc. Publication, New York.

r.. Denizot F, Lang R. Rapid Colorimetric A for cell growth and survival :modification of the tetrazolium dye procedure giving improved sensitivity and reliability. J Immune Methods 1914;^9:YVI_. VV.

rv. Takimoto CH. Anticancer Drug Development at the US National Cancer Institute " .Cancer Chemother. Pharmacol. r..r; or (suppl I) : Srq_r.

r^. Wilson AP. Cytotoxicity and viability assays In : J. R. W. Maslers (ed) .Animal cell culture: A practical Approach. Oxford University Press, Oxford: $\mid V_{-}$Y 19.

rq. Geary WJ. Coord Chem. Rev.19Y1; $\vee: \wedge$. 
$r \cdot$ Deacon GB, Philips RJ. Coord Chem Rev191.;rr:rrv.

r.. Das RC, Mishra MK, Moharty MK. J Indian Chem Soc 19^.; $\mathrm{V}:$ T TV.

rr. Vicente J, Chicote M.J, Arcas A, et al. Organomet. Chem. 19人r; $r \leqslant V: Y r$.

rr. Kahn O. . Molecular Magnetism, VCH Weinbeim .1994.

rร. Bayoumi HA, Shoukry EM, Mostafa MM., N-r-[ $\leqslant, \Upsilon_{-}$ dimethylpyridyl] $\quad-\mathrm{N}$ Phenylthiourea Transition Metal Complexes .Synth. React. Inorg. Met. Org. Chem. r... ; r), ovq

ro. Kubo K, Nakano M, Tamura H, et al. Organomet. Chem. r..r; 779 , I $\leqslant 1$

чч. Ronconi L, Marzano C, Zanell P, etal. Cold(III) Dithiocarbamate Derivatives for the Treatment of Cancer : Solution chemistry, DNA Binding and Hemolytic Properties. J Med Chem r.. $; ; \leqslant 9(0): 17 \leqslant \Lambda$ 170\%.

rv. Casini A, Kelter G, Gabbiani Ch, et al. Chemistry, antiproliferative properties, Tumor Selectivity, and Molecular Mechanisms of Novel Gold(III) Compounds for Cancer Treatment: a Systematic Study. J.

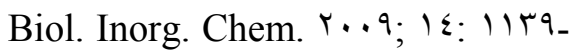
$11 \leqslant 9$.

r^. Casini A, Hartinger Ch, Gabbiani $\mathrm{Ch}$, et al. Gold(III) compounds as anticancer agents : Relevance of gold-protein interactions for their mechanism of action. $J$ Inorganic Biochem $r \cdot \cdots \cdot 1 \cdot r(r): 0 r \varepsilon-v 0$.

rq. Gabbiani Ch, Casini A, Messori L. Gold(III) Compounds as Anticancer Drugs. Gold Bulletin. r... $; \varepsilon \cdot(1): V^{\top}-\Lambda$. .
¿. Bruni B, Guerri A, Marcon G, et al. Structure and cytotoxic properties of some selected gold(iii) complexes. Croatica Chemica Acta. $\left.1999 ; V Y\left(Y_{-} r\right), Y_{Y}\right)_{-}$.

\&). Toyozumi $Y$. International $J$

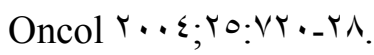

\&r. Che CM. Chem Commun (camb) r..r;rI:IVIN.

«r. Coronello M. , Mini M. , Caciagli B, et al. J Med Chem r...o; 纟八:TVฯ).

ะs. Wang Y, He QY, Che CM, Chiu JF. Proteomics $r \ldots r ; \tau, 1 r 1-\varepsilon r$.

Ło. Rigobello MP, Messori MP, Marcon G, et al. Inorg. Biochem.. ${ }^{\prime} . . \varepsilon ; 9 \Lambda, 17 r \varepsilon$.

ะ7. Rigobello MP, Scutari A, Folda G, Bindoli A. Bio Chem. Pharmcol

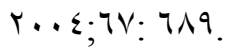

¿v. Omata Y. Toxicol. In Vitro . r.. r; r., MAr-q. 